\title{
STUDIES ON AUSTRALIAN MOLLUSCA.
}

Part VIII. By C. Hedley, F.L.S.

With a Note on Terebra HedLeyi, Tate.

By Edgar A. Smith, Assistant Keeper of Zoology, Natural History Museum, London.

(Plates viii.-x.)

(Continued from Vol. xxvii., p. 619.)

Flammulina mathinne, Petterd.

Helix mathinne, Petterd, Mon. Land Shells of Tasmania, 1879 , p. 26.

$$
\text { (Plate viii., figs. 4-6.) }
$$

This species has not yet been figured. I am indebted to Mr. Alex. Morton for an opportunity of filling the gap. The drawings now presented are based on a type specimen, the dimensions of which are maj. diam. $5 \mathrm{~mm}$; min. diam. $4.15 \mathrm{~mm}$; height $2.65 \mathrm{~mm}$.; now in the collection of the Tasmanian Museum.

Endodonta hookeriana, Johnston.

Helix hookeriana, Johnston in Petterd, Mon. Land Shells of Tasmania, 1879, p. 38 .

(Plate viii., figs. 1-3.)

I am also indebted to Mr. Morton for the opportunity of drawing this species from the type in the Tasmanian Museum. Its dimensions are, maj. diam. $1.75 \mathrm{~mm}$; min. diam. $1.5 \mathrm{~mm}$; height $0.8 \mathrm{~mm}$. 
Coxiella Badgerensis, Johnston.

The genus Coxiella was founded by Smith* on Truncatella striatula, Menke, a native of West Australia. In Dr. Cox's 'Monograph of Australian Land Shells,' two species of this genus were distinguished, but the striatula of Menke was redescribed as a new species, Blanfordia pyrrhostoma, while Menke's name was attached to the eastern species. This reversal of nomenclature confused Smith, who, in establishing his genus, recognised but one species.

Later I invited $\dagger$ Mr. Smith to reconsider his decision. $\mathrm{He}$ accordingly re-examined the subject $\ddagger$ and separated, as suggested, three species, the western $C$. striatula, Menke, the central $C$. gilesi, Angas, and the eastern form for which he coined a new name, C. confusa, Smith.

It unfortunately escaped his notice that a name for the eastern species already existed, viz., Potamiopsis badgerensis, described as fossil from Badger Island, Bass Straits, by R. M. Johnston. $\$$ This name its author was afterwards inclined to discard $\|$ as superfluous. Tate \& May recognise Johnston's fossil as identical with $C$. confusa, Smith. I have also the assurance of Mr. W. F. Petterd, who is better acquainted with the species than myself, that $C$. badyerensis cannot be specifically distinguished from the recent shell. It follows, therefore, that the earlier name of Johnston must replace the doubly appropriate Coxiella confusa, Smith.

\section{Heterocyclus Petterdi, Smith.}

$$
\text { (Plate viii., fig. 7.) }
$$

The accompanying figure is drawn from one of the original specimens of Bythinia richmondiana, Petterd, ${ }^{* *}$ which the author

* Proc. Mal. Soc. i. 1894, p. 98.

+ Proc. Mal. Soc. i. 1895, p. 260.

† Proc. Mal. Soc. iii. 1898 , p. 76 .

$\S$ Proc. Roy. Soc. Tas. 1878, p. 26.

$\|$ Geol. Tas. 1888, p. 329.

- These Proceedings, xxvi. p. 449.

** Journ. of Conch. iv. 1884, p. 159. 
of the species kindly placed at my disposal. This name has to yield to the prior Hydrobia petterdi, Smith. * To the same species is referred Pupa anodonta of Musson and myself, $\uparrow$ later transferred to Heterocyclus. $\ddagger$ It has, with the following species, been traced by Dr. T. May as far north as Bundaberg.

\section{Petterdiana brazieri, Smith.}

Mr. W. F. Petterd has also kindly communicated examples of his Amnicola positura, $\S$ which prove to be synonymous with the earlier Hydrobia brazieri, Smith.|| The species ought, I think, to be included in the genus Petterdiana, of which it is the only representative in this State.

\section{Bittium furvum, Watson.}

Watson, Chall. Rep. Zool. xv., 1886, p. 556, pl. xxxviii., f. 5.

This reference has always been a trouble to Australian students. I have at last identified the shell as the young of Cerithium icarus, Bayle $=C$. tenue, Sowb. not Desh. $=$ B. variegatum, Braz.

\section{Rissoa agnewi, Tenison Woods.}

Ten. Woods, Proc. Roy. Soc. Tas. 1876, [1877] p. 152.

I submitted specimens dredged in 100 fathoms 16 miles east of Wollongong to Mr. W. L. May, who writes (12:ii.: 1904) that he thinks they are a variety of that species, from the type of which they differ by having apparently one whorl less, and by a blunter apex; but with which they agree in sculpture and general form. Mr. May now considers that the illustration given as of this species really represents $R$. layardi, Petterd, a different species. In the forthcoming issue of the Proceedings of the

* Journ. Linn. Soc. Zool. xvi. 1882, p. 270, pl. vii., f. 23.

† These Proceedings (2) vi. 1892, p. 558.

† These Proceedings (2) vii. 1893, p. 373.

$\S$ Journ. of Conch. iv. 1884, p. 159.

|| Journ. Linn. Soc. Zool. xvi. 1882, p. 270, pl. vii., f. 21.

T These Proceedings, xxvi., pl. xxvi., f. 70. 
Royal Society of Tasmania he will give a figure of the type of $R$. agnewi. This species is an addition to the known fauna of this State.

Rissoa integella, n.sp.

(Plate ix., fig. 20.)

Sheli tall, slender, subcylindrical, imperforate, thin, translucent. Colour uniform white. Whorls nine, including the globose, spirally grooved protoconch of one whorl, rounded, constricted at the sutures. Sculpture: sharp, spiral keels which multiply from three on the first to eight on the last whorl. The interstices are latticed with faint lines, and under a high magnification are further seen to be ornamented by fine, dense, spiral scratches. Aperture subcircular, outer lip bearing a rather strong varix, inner lip reflected over an umbilical furrow. Length $4.85 \mathrm{~mm}$.; breadth $1.35 \mathrm{~mm}$.

Hab. - Sixteen miles east of Wollongong in 100 fathoms; a few specimens dredged by Mr. G. H. Halligan and self.

T y p e.-To be presented to the Australian Museum.

\section{Epigrus protractus, n.sp.}

(Plate viii., figs. 8-11.)

Shell minute, cylindrical, thin, translucent, glossy, with the last whorl uncoiled. Colour pale ochre, with a more ruddy tint on the peristome. Whorls four and a half. First whorl and a half globose, tilted; second and third rounded, deeply contracted at the suture, which is margined; last half-whorl free and stretched out in the direction of the shell's axis. Aperture circular, very oblique; peristome broad, expanded. Length $1.3 \mathrm{~mm}$.; breadth $0.36 \mathrm{~mm}$.

Hab._Chinaman's Beach, Middle Harbour; several specimens, taken by my friend Miss L. Parkes.

Ty p e.-To be presented to the Australian Museum.

To the information given on this genus in the Report on the Thetis Gasteropoda* I can now add that I lately had the pleasure

*Hedley, Mem. Aust. Mus. iv. 1903, pp. 355, 356. 
of showing E. ischnus to Mr. W. L. May, and that he recognised it as $E$. simsoni, Tate \& May. Of the united names Epigrus ischnus, Tate, takes precedence

\section{Planaxis brasilianus, Lamarck.}

Several names have been proposed for this species.* Commencing with Angas, $\uparrow$ writers on Australian Mollusca have unanimously selected Planaxis mollis for employment. Pritchard \& Gatliff $\ddagger$ alone do so definitely on the ground of priority. But this involves chronological error. Buccinum brasilianum, Lamarck, $\S$ appeared in August, 1822. Planaxis mollis, Sowerby, \| was undated on the title page of Part or Volume.

We learn, however, from Newton 9 that Planaxis was included in Part xii. of Sowerby's "Genera," and we further ascertain from Sherborn** that Part xii. was issued February 3rd, 1823. This, then, is the date to be assigned to Planaxis mollis.

Those who, like Brazier, $\uparrow \dagger$ might prefer P. mollis to P. brasilianus, because the latter is a misnomer, are reminded of the rule of zoological nomenclature adopted by the Fifth International Congress of Zoology: "A name once published cannot be rejected, even by its author, because of inapplicability."

Sowerby went as far astray in the habitat as Lamarck did, for he considered $P$. mollis to be a British species. I have already shown $\ddagger$ that the type of $P$. brasilianus was apparently collected by a Sydney resident. Suter enlarges the known range of the species by reporting it from New Zealand.\$\$

* Smith, Ann. Mag. Nat. Hist. (4) ix. 1872, p. 46.

† Proc. Zool. Soc. 1867, p. 210.

$\ddagger$ Proc. Roy. Soc. Vic. n.s. xiv. 1902, p. 87.

$\S$ Anim. s. Vert. vii. p. 272.

|| Genera of Shells ii., Explanation to Pl. 209.

ๆ Brit. Mus. Cat. Edwards Coll. 1891, p. 321.

** Ann. Mag. Nat. Hist. (6), xiii. 1894, p. 371.

†† These Proceedings, (2) ii. 1888, p. 999.

$\ddagger+$ These Proceedings, xxvii. p. 24, footnote.

$\S \S$ Index Faunæ Novæ Zealandiæ, 1904, p. 76. 
Leucotina micra, Pritchard \& Gatliff.

Turbonilla (Ondina) micra, Pritchard \& Gatliff, Proc. Roy. Soc. Vic. n.s. xiii., Aug., 1900, p. 134, pl. xxi., f. 1.

This species extends north to New South Wales. The single haul of the dredge made by Mr. G. H. Halligan and self in 100 fathoms, 16 miles east of Wollongong, yielded a few examples. Under the name of Syrnola micra, it has been catalogued by Tate \& May* from Tasmania. I prefer to regard it as a Leucotina, for the punctured grooving is a feature foreign to either Turbonilla or Syrnola.

\section{Daphnella Cassandra, n.sp.}

(Plate viii., fig. 17.)

Shell small, slender, tall, moderately solid. Colour white (? bleached). Whorls seven, including a two-whorled exsert protoconch; angled at the suture. Sculpture: small, sharp, spiral threads, on the earlier whorls three, on the last about ten; above these threads are widely spaced, but on the base crowded. Their interstices are latticed by growth-lines. Aperture narrow, oblong, canal short. Length $5.15 \mathrm{~mm}$; breadth $1.6 \mathrm{~mm}$.

Hab.-Balmoral Beach, Sydney (Mrs. C. H. Starkey; type); Frederick Henry Bay, Tasmania (W. L. May).

Ty p e.-To be presented to the Australian Museum.

Shortly before his death, I sent this species to the late Prof. Tate, suggesting that it might be the unrecognised Cingulina brazieri. Prof. Tate penned a brief note, almost his last scientific work, adopting my suggestion and proposing the new name Terebra hedleyi for Cingulina brazieri. $\dagger$ The untimely decease of my friend, and the loss of a drawing I had prepared, complicated matters. Since then Dr. Pilsbry has named a Japanese shell Terebra hedleyi $i_{+}^{+}$Mr. E. A. Smith writes that C. brazieri is not the species before us, and I therefore formally propose the

* These Proceedings, xxvi., p. 382, pl. xxv. f. 54 .

† These Proceedings, xxvi. 1901, p. 214.

$\ddagger$ Pilsbry, Proc. Acad. Nat. Soc. Philad. 1904, p. 3, pl. i., f. 1. 
latter as a new species. For critical remarks on Cingulina brazieri, the reader is referred to an appendix to this paper, kindly contributed by Mr. E. A. Smith (postea, p. 211).

\section{Strombus urceus, Linn.}

Strombus urceus, Linn., Syst. Nat. x. 1758, p. 745.

It has been pointed out by Hanley* that this Linnean name has been always misapplied. He stated that Linné's type (well represented by Thes. Conch. i. pl. vii., f. 45) is identical with Strombus floridus, Lamarck. But the species commonly known as $S$. urceus, Linn., is rightly S. ustulatus, Schumacher.

This information is not new; but as every writer on Australian Mollusea, from Angas in 1867 to Pritchard and Gatliff in 1900 , has gone astray in the matter, it seems well to here restate the facts.

\section{Acmea octoradiata, Hutton.}

Patella octoradiata, Hutt., Cat. Marine Moll. N.Z. 1873, p. 44. Acmcea saccharina, Linn., var. perplexa, Pilsbry, Man. Conch. xiii. 1891 , p. 50, pl. xxxvi., figs. $69,70,71$.

Pilsbry cites Hutton's name with doubt as belonging to his variety. Following this suggestion, I sent a series of this shell from Maroubra Bay to Prof. Hutton, who kindly replied (2 : iv. :'04), "The Acmea is truly my Patella octoradiata. I withdrew it from my second edition because I doubted the correctness of the locality. But since then it has been again found in New Zealand."

I agree with Taylor $\uparrow$ and with Pritchard \& Gatliff + in regarding the form under notice as a valid species. In reviving Hutton's prior name, another species is added to those common to Australia and New Zealand.

Since writing this note, I have received from Captain Hutton his 'Index Faunæ Novæ Zealandiæ,' in which (p. 85) the above synonymy is for the first time recognised.

* Ips. Linn. Conch. 1855, p. 275.

+ Nautilus vi. 1892 , p. 89 .

$\ddagger$ Proc. Roy. Soc. Vict. xv. n.s. 1903, p. 194. 
Acmea alticostata, Angas.

From Port Lincoln, S.A., Angas described* Patella alticostata. $\mathrm{He}$ afterwards noted and briefly described $\dagger$ the same shell as Patella costata, Sowerby, from Coogee and Wollongong, N.S. Wales. But he failed to explain whether he had withdrawn or only forgotten his own name. Boog Watson notes the species $\ddagger$ as P. alticostata, Angas, from Port Jackson, without allusion to A. costata. Subsequent authors have united the names and confounded the two species. The reference to Sowerby given by Angas is incorrect, but it indicates "Lottia? costata," Sowerby, from "? Coasts of Pacific Ocean."

It does not seem to be generally known that there are two species of Acmea somewhat alike, the one inhabiting the Central and South-Eastern Pacific, the other temperate Australia. The Australian is larger, more solid, more elevated, with about eighteen subequal ribs, the black border of the inside edge usually continuous. From the Gambier Islands I have seen examples agreeing with Sowerby's figure, in which the black border is interrupted by the cords of the ribs: between the larger ribs smaller ones are intercalated, and between the latter still smaller ones. Patella stellaeformis, Reeve, seems to me a variety of $A$. costata, Sowerby.

To clinch the argument that $A$. costata and A. alticostata are different species, the former Pacific, the latter Australian, I would remark that Capt. Beechey does not appear to have touched during the voyage of the "Blossom" at places where the latter species was procurable, but during his survey of the Gambier Islands he would have had the opportunity of gathering the former.

Strebloceras Cygnicollis, n.sp.

(Plate viii., figs. 12-14.)

Shell minute, glassy, translucent. The apex lateral, of two whorls in one plane; remainder describing half a revolution of a

* Proc. Zool. Soc. 1865, p. 56, pl.ii., fig. 1 .

† Proc. Zool. Soc. 1867, p. 221.

$\ddagger$ Chall. Rep. xv. 1886, p. 26.

$\S$ Zool. Beechey's Voy. 1839, p. 147, pl.xxxix., f.1. 
long-drawn spiral in a plane oblique to the first. At one-fifth of the length a stout projecting ring-varix occurs. Sculpture: delicate growth-rings, which latterly become broader and stronger. Aperture simple, circular, oblique to the plane of growth, nearly at right angles to the plane of apex. Length (straight line between most distant points) $3.35 \mathrm{~mm}$; diameter of aperture $0.45 \mathrm{~mm}$; diameter of apex $0.1 \mathrm{~mm}$.

Hab. - Bottle and Glass Rocks and Long Bay, near Sydney; three specimens (Miss L. Parkes).

T y p e.-To be presented to the Australian Museum.

This species adds to the Australian fauna a genus which was founded by Carpenter* for the reception of a Tertiary fossil. The first recent species was discovered near Honolulu by the Challenger Expedition. From it, this, the second, is easily distinguished by more slender form and conspicuous ring-varix. The latter character strikingly recalls Ctiloceras.

\section{Capulus devotus, n.sp. \\ (Plate viii., figs. 15-16.)}

Shell small, rather solid, elevated, irregular, asymmetrical; apparently without epidermis. Colour white. Sculpture : delicate regular concentric hair-lines. Protoconch sharply defined, of a whorl and a half, smooth. Apex projecting far past the base. Adult shell describing a quarter of a whorl, rapidly increasing, wound in a different plane to the embryo. Aperture subcircular, simple, slightly expanded. Specimen drawn, from back to front $4.5 \mathrm{~mm}$.; base to vertex $3.5 \mathrm{~mm}$.; side to side $3.0 \mathrm{~mm}$. Another specimen, $5.5 \times 4.0 \times 5 \cdot 1 \mathrm{~mm}$.

Hab.-Sixteen miles east of Wollongong in 100 fathoms; several specimens dredged by Mr. G. H. Halligan and self.

T y p e.-To be presented to the Australian Museum.

The lack of colour and rotund form easily distinguish this from C. violaceus, Angas, the only other member of the genus native to our coast. 
Atys pransa, n.sp.

(Plate ix., figs. 21-22.)

Shell ovate, solid, smooth, glossy. Colour pale cream. Sculpture : faint, spaced, incised, spiral lines, more crowded and conspicuous at either end, and obsolete in the centre. Aperture the length of the shell; above pinched in a narrow loop, below rounded; outer lip arcuate, bent and slightly reflected at the upper and lower insertion; inner lip spreading, a callus on the body-whorl. Deeply narrowly perforate above and below. Length $5.0 \mathrm{~mm}$; breadth $2.55 \mathrm{~mm}$.

Hab.-Sixteen miles east of Wollongong in 100 fathoms; one specimen dredged by Mr. G. H. Halligan and self.

Ty p e.-To be presented to the Australian Museum.

\section{Phos tabidus, n.sp. \\ (Plate viii., fig. 18.)}

Shell tall, slender, thin. Whorls six, slightly angled. Colour grey, obscurely banded with reddish-brown. Sculpture : on last whorl twenty sharp but low radial plications which commence at the sutures and gradually vanish on the base. Both plications and interstices are crossed by regular, evenly spaced, spiral cords, of which the last whorl has twenty, five of which run between the suture and the angle. This sculpture is continued on the earlier whorls, and fades away gradually at the protoconch, which is large, dome-shaped, of two whorls, smooth and glossy. Aperture ovate, outer lip simple; canal short, bent to the left. Columella much arched, overlaid by a callus sheet, its lower extremity furrowed by a deep spiral groove. Length $12 \mathrm{~mm}$; breadth $5 \mathrm{~mm}$. The specimen here described is immature.

$H a b$.- Sixteen miles east of Wollongong in 100 fathoms; a few imperfect specimens dredged by Mr. G. H. Halligan and self.

Ty p e.-To be presented to the Australian Museum.

This species is assigned to the genus Phos, in accordance with the views of the late Prof. Tate.* I am not satisfied that this

* These Proceedings, xxvi. p. 454. 
classification is correct, but adopt it as a temporary expedient pending the receipt of further information. The only known living relation is the Tasmanian Phos tenuicostatus, Ten. Woods, from which the northern shell is discriminated by its small and slender form and less development of longitudinal sculpture.

\section{Stiva, n.g.}

Allied to Rissoina. Shell with the contour of Scala rather than Rissoina; large, tapering, solid. Operculum peltate, concentric.

\section{Ty pe S.ferruginea, Hedley.}

The remarkable operculum, the chief foundation of the genus, has a limb resembling that of Jeffreysia, as figured by Alder,* which has, however, the nucleus submarginal.

\section{Stiva Ferruginea, n.sp.}

(Plate ix., figs. 23-25.)

Shell tall and tapering, very solid, smooth and glossy, a little contracted at the sutures, last whorl subangled at periphery; sometimes decollate and plugged. Colour rusty red, yellow on apex and between the ribs, with a faint, narrow, white peripheral band. Whorls ten, counting the dome-shaped protoconch of two and a half whorls. Suture deeply impressed, undulated by the ends of the ribs. Sculpture: apex smooth, ribbing gradually commences on the third whorl, increasing in strength but not in number to the last. Ribs longitudinal, broad, curved, undulating, ten on last whorl, twelve on penultimate, fading away on base. Under the lens appear fine, dense, wavy scratches crossing both ribs and interstices. Aperture fortified externally with a varix; inner lip very thick, forming a free edge; anteriorly the aperture contracts to a short, shallow, oblique spout. Operculum (figs. 24, $25)$ peltate, elevated, not spiral, apex excentric, from the apex a furrow runs to the farthest margin, from the lower corner of the

* Ann. Mag. Nat. Hist. (2), vii. 1851, p. 194. 
underside projects a spoon-shaped limb. Length 18; breadth $7 \mathrm{~mm}$.

Hab. - Sixteen miles east of Wollongong in 100 fathoms; several specimens dredged by Mr. G. H. Halligan and self.

Ty p e.-To be presented to the Australian Museum.

\section{The Eggs of Lotorium spengleri.}

(Plate viii, fig. 19.)

Numerous specimens of Lotorium spengleri, Chemnitz, were discovered (16:x. :'03) in the act of ovipositing in rocky pools at low-tide mark in Sydney Harbour. The eggs were concealed under the bodies of the parents. From the nest figured I forcibly removed the mollusc. In shape the mass resembled a peach split down the centre, the cavity answering to that occupied by the peach stone. Each mass, pale yellow in colour, firmly adhered by its base to the rock, and was usually torn in removal. The example drawn weighed $2 \frac{1}{4}$ ozs., and measured $60 \mathrm{~mm}$. in diameter and $35 \mathrm{~mm}$. in depth. The eggs are packed in a tough, semitransparent cup-shaped membrane, externally with close imbricating scales; the margin is shortly folded over the eggs in the interior. The capsules are conical, about $10 \mathrm{~mm}$. long, their base attached to the inner wall of the envelope, their apex projecting into the central hemispherical cavity. They are densely packed, tier above tier, and are probably laid in spirals; the top tier held about thirty-five capsules.

Chione despecta, n.sp.

$$
\text { (Plate x., figs. 35-38.) }
$$

Shell small, solid, triangularly ovate, equilateral. Colour grey. Sculpture: radials none; concentric, about twenty fine, thin, elevated, upturned, spaced lamellæ, which traverse the whole shell. In their interstices are fine microscopic concentric threads. Lunule faintly impressed, short and narrow. Dorsal area not differentiated. Umbo prominent. Inner ventral margin crenulated. Pallial sinus short and shallow. Hinge : left valve with 
two papillate, cardinal teeth enclosing a deep, narrow fossette which received the single well-developed cardinal of the right valve. Length 3.5 ; height 3.0 ; diam. of single valve $1.1 \mathrm{~mm}$.

Hab.-Sixteen miles east of Wollongong in 100 fathoms; a few separate valves dredged by Mr. G. H. Halligan and self.

Ty p e.-To be presented to the Australian Museum.

The lack of radial sculpture distinguishes this from related forms; it is besides the smallest of the genus. The observations on the exceptional hinge require to be checked on fresh material.

Chione nitida, Quoy \& Gaimard.

Venus nitida, Quoy \& Gaim., Voy. Astrolabe, Zool. iii. 1835, p. 529, pl. lxxxiv., figs. 13,15 (not 13, 14, as quoted in the text).

Venus fumigata, Sowerby, Thes. Conch. ii. Venus, 1853, p.737, pl. clix., figs. 152-155.

Venus lavigata, Sowerby, op. cit., p. 738, pl. clix., fig. 158.

The original locality for this species is Hobart, Tasmania. It was characterised by its authors as one inch long, smooth, glossy, oval wedge-shaped, inequilateral, the rounded anterior end shortest, the posterior produced and rather abruptly angled, without a lunule, exterior a uniform clear brown, interior bright orange.

The misprint by which "fig. 14" has been exchanged for "fig. 15 " has, perhaps, led to confusion. At first sight, fig. 13 of the Astrolabe plate appears to represent a valve concentrically corrugated, but in view of the insistence of the text that the shell is smooth (Venus polie-Venus nitida-Venus...polita-Cette Venus est lisse), the darker spaces should be read as colour bands.

The London conchologists, as usual, made no effort to recognise this species previously named by the French naturalists, and, as usual, renamed it when they met it. So it has practically passed into oblivion. Messrs. Tate \& May subordinate it with a query* to Meretrix planatella, and Messrs. Pritchard \& Gatliff follow their example with doubt $\dagger$

* Tate \& May, Proc. Linn. Soc. N.S.W. xxvi. 1901, p. 428.

+ Pritchard \& Gatliff, Proc. Roy. Soc. Vic. xvi. (n.s.), 1903, p. 130. 
It is here submitted that the orange-tinted interior is a valid recognition-mark whereby we may prove Venus nitida to be the species usually known as Venus lavigata, Sowerby. The remainder of the characters, the size and habitat conform to this conclusion. I submitted this idea to my friend, Mr. W. L. May, and inquired if the naturalists of the Astrolabe would have been likely to meet with $V$. laevigata on the beaches round Hobart. He replied (18:ix. :'03) :-“ “I should think your view is probably right. Prof. Tate thought nitida might be a synonym of $C$. planatella, but I now think that is a mistake. I do not think pianatella is found in the Derwent, whilst C. lavigata would be, and the description and figures, as you say, seem to fit the latter well. The numbering of the Astrolabe plate is wrong, the two valves on the left being nitida."

The species whose figure and description follow in the Voyage of the Astrolabe that of $V$. nitida, namely, $V$. denticulata, appears to me from its purple interior to be Chione gallinula, Lamarck.

Dr. W. H. Dall included V. fumigata, Sowb., in his new section Macridiscus.*

\section{Cardium bechei, Reeve.}

It has escaped the attention of all subsequent writers, even absurd to say, that of Reeve himself, that this species was first described in the Proceedings of the Zoological Society for 1847, p. 25 (April 13, 1847). For it is always referred to as of Adams \& Reeve, and quoted as dating from the 'Voyage of the Samarang.' The species has occurred at the Tweed Heads, and so just falls into the category of New South Wales mollusca. Brazier has mentioned it $\uparrow$ from several localities in Queensland, and Melvill and Standen $\ddagger$ note it from Warrior Island. I have drawn attention $\S$ to its possible identity with the fossil $C$. antisemigranulatum, McCoy.

* Trans. Wagner Inst. iii. 1903, p. 1289.

+ These Proceedings, i. 1876, (1877) p. 306.

‡ Journ. Linn. Soc. Zool. xxvii. 1899, p. 192.

$\S$ Mem. Aust. Mus. iv. 1902, p. 288. 
Psammobia lessoni, Blainville.

So far as I can ascertain, this is the proper name for the Sydney shell reported as Gari malaccana, Reeve, by Angas.* The species was figured by Reeve, $\uparrow$ who referred in his careless way to Blainville's name as a manuscript one. Blainville, however, fully described the speciest from specimens collected by Lesson in the Moluccas.

Fischer noted G. lessoni from Ile Art, New Caledonia.\$ It occurs along the whole coast of Queensland. In our latitude this straggler from the tropics is smaller, and less brightly coloured than northern examples.

\section{Diplodonta zelandica, Gray.}

Jointly with Messrs. H. Suter and W. L. May, who discussed the matter with me, I can now announce that $D$. tasmanica, Ten. Woods, is an absolute synonym of the above name. The species has not hitherto been recognised from this State. Its northern limit is indicated to me by a gigantic example from Port Stephens measuring $34 \mathrm{~mm}$. in length and $30 \mathrm{~mm}$. in height.

It was first described as Lucina zelandica by Gray.\| His type was afterwards figured in the 'Zoology of the Erebus and Terror' (1874, Moll., pl.iii., f. 8).

Under the name of Lucina inculta it was again figured and described by Gould from New Zealand.

Thirdly, it was named Diplodonta tasmanica by Tenison Woods.** A Tasmanian specimen was figured in these Proceedings (Vol. xxviii., pl. xxvii., f. 102).

* Proc. Zool. Soc. 1867, p. 917.

+ Conch. Icon. x., Psammobia, 1856, pl. ii., f. 8.

$\ddagger$ Dict. Sci. Nat. xlii. 1826, p. 480.

$\S$ Journ. de Conch. vii. 1859, p. 336.

\|I Yate, 'Account of New Zealand.' Appendix. 1835, p. 309. Both the first and second editions of this work are dated 1835 .

T Am. Expl. Exped. Moll. xii. 1852, p. 412, pl. xxxvi., f. 524.

** Proc. Roy. Soc. Tas. 1876, p. 158. 
Thraciopsis arenosa, n.sp.

(Plate ix., figs. 26-27.)

Shell small, oblong, equilateral, anterior dorsal margin concave, posterior dorsal margin convex, tapering more anteriorly than posteriorly. Colour grey, with radiating and concentric lines of pale yellow. Sculpture : the whole shell is densely covered with small but sharp, elevated grains arranged radially. Height $2 \cdot 9$, length $4.55 \mathrm{~mm}$.

$H a b$. - Sixteen miles east of Wollongong in 100 fathoms; dredged by Mr. G. H. Halligan and self.

Ty p e.-To be presented to the Australian Museum.

This species is represented only by a single left valve. The sculpture, like sand-paper, is a remarkable character, and members of this genus are usually inequilateral. Though more material is requisite for a full description, these peculiarities should ensure recognition.

\section{Cardita dilecta, Smith.}

Smith, Chall. Rep. Zool. xiii. 1885, p. 213, pl. xv., f. 4.

This pretty species extends to the waters of this State, for it was included in the rich haul made by Mr. G. H. Halligan and self in 100 fathoms, 16 miles east of Wollongong. It has not been seen since its discovery in Bass Straits by H.M.S. 'Challenger,' thirty years ago.

\section{Zenatia victorie, Pritchard \& Gatliff.}

Pritchard \& Gatliff, Proc. Roy. Soc. Vic. n.s. xvi. 1903, p. 92, pl. 15 , f. 3 .

This species also reaches New South Wales. I saw it frequently on the beach at Boyd Town, Twofold Bay, and have taken a broken valve in Middle Harbour. It is evidently the species which Angas reports* under the erroneous name of $Z$. acinacies, Quoy \& Gaimard, from Botany Bay. Mr. O. Thiele informs me that he observed it at Snake Island, Victoria.

- Proc. Zool. Soc. 1867, p. 917. 


\section{Crassatellites ponderosus, Gmelin.}

In the opinion of Messrs. E. A. Smith* and J. Brazier, $\uparrow$ all the large Australian Crassatellites, viz., C. kingicola, Lamk.; $\boldsymbol{C}$. donacina, Lamk.; C. castanea, Reeve; $C$. decipiens, Reeve; $C$. errones, Reeve; $C$. pulchra, Reeve, and C. cumingi, A. Adams, are referable to one species. For the first or for the aggregate, Australian conchologists, misled by European authors, have taken unquestioned the name of Crasatella kingicola, Lamarck.

Suspicion that there was a flaw somewhere in the nomenclature was aroused by a statement by Woodward $\$$ that the type of Crassatella is an Australian shell, C. ponderosa. This species does not appear in Australian Catalogues, nor is it cited in any monograph of the genus. Search in literature elicited the following information.

The first appearance of our shell in literature was by Chemnitz.\| So far as I can gather, this was in a serial published at Halle in Germany. The first reference that $I$ have seen is by Chemnitz, in the first edition of the Conchylien Cabinet (Vol.vii. 1784 , p. 61 , pl. lxix., f. A, B, c, D), as Venus-plumbea-Oceani-australis, \&c.). As Chemnitz did not then use Linnean binomials, his name has, for systematists, only an historical interest. The Chemnitzian figure approximates to that given by Chenu $\boldsymbol{\top}$ for $C$. donacina, or that given by Reeve** for C. pulchra.

Gmelin, upon this account by Chemnitz, founded his species Venus ponderosa. †† Gmelin, who only knew the species from the drawing, incorrectly gives "margine crenulato," as a character. His error is obviously based on the fact that the artist used a dotted line to represent the inner edge of the valve margin.

* Rep. Zool. Coll. Alert, 1884, p. 108.

+ These Proceedings, (2) ix. 1890, p. 749.

$\ddagger$ Manual, p. 466, Explanation to pl. xxi., f. 4.

$\S$ Fide von Martens, Malak. Blatt. xix. 1872, p. 30.

I| Naturforscher, xix., 1783, p. 185, pl. viii.

- Illustr. Conch. Crassatella, 1850, pl. ii.. f. 15.

**Conch. Icon. i. Crassatella, pl. iii. sp. 16, 1843. †十 Syst. Nat. xiii. 1790, p. 191. 
The pallial line, which could hardly be "crenulated," is indicated by a similar dotted line.

A French fossil which actually had a crenulated margin occurred to Lamarck, so, misled by Gmelin, he naturally referred it to the Chemnitzian species. To the fossil he gave the name of C. tumida.* But he had previously bestowed the name C.gibba ${ }^{*}$ upon the figures of Chemnitz. On material gathered by Péron, he erected Crassatella kingicola. $\dot{\ddagger}$

Dillwyn adapted, as his custom was, the name from Chemnitz of Venus plumbea.\$

I have nothing to add to the range of this species in New South Wales recorded by Brazier, viz., off Merimbula, in 17 fathoms, and the beach at Ballina.

\section{DaCRydium fabale, n.sp.}

(Plate x., fig. 39.)

Shell minute, thin, semitransparent white with iridescent reflection. Short, broad and inflated; umbo slightly projecting, dorsal margin arched, ventral sinuate. No radial sculpture, delicate, concentric growth-lines which rise into ridges on the ventral side. Hinge : a deep chondrophore, flanked by two prominent grooved cardinals; the dorsal interior margin carries a long, crenulated band, which is absent on the opposite side. Height 2.8 ; length 2.0 ; diameter of single valve $0.8 \mathrm{~mm}$.

Hab.-Sixteen miles east of Wollongong in 100 fathoms; several specimens dredged by Mr. G. H. Halligan and myself.

Ty p e.-To be presented to the Australian Museum.

This species adds a genus to the Australian fauna. The contour and especially the ventral sinuation effectually separate it from other members of the genus.

* An. s. Vert. v. 1818, p. 418.

$\uparrow$ Syst. des. An. s. Vert. 1801, p. 119.

$\ddagger$ Ann. du Mus. vi. 1804, p. 408.

$\S$ Descr. Cat. Rec. Shells, i. 1817, p. 191. 


\section{Mytilus erosus, Lamarck.}

Lamarck, Anim. s. Vert. vi. 1819, p. 120.

This species, described from "New Holland," and probably from Péron's collection, has been forgotten by modern writers. Gray observed it as occurring in Capt. King's Australian Collection,* and Forbes $\dagger$ reported it definitely as found on Zostera flats at Port Dalrymple in Northern Tasmania.

There can scarcely be a doubt that this is the shell usually known as Mytilus menkeanus, Philippi,-a MS. name in the Cumingian Collection put into circulation by Reeve. $\ddagger$ Probably it is also the species catalogued by Menke from various places in West Australia under the name of Mytilus magellanicus, Chemnitz.

It has only occurred in New South Wales as a subfossil in raised beaches at Maitland.

\section{LiMa SYDNEYENSIS, nom. mut.}

Under the name of Lima brunnea I described an Australian shell. I now find that A. H. Cooke previously used** the same name for a Suez species; and accordingly change my name as above.

Contrary to the rules for the proposal of new species, Cooke's Lima irunnea was buried in the text, concealed in a tabular list; and has consequently been omitted from the Zoological Record, and from subsequent literature. His scanty diagnosis is probably insufficient for the recognition of the species. Such objectionable work is to be dreaded by systematists, as an uncharted reef is dreaded by mariners. And as such a reef may by the erection of a beacon be made a help instead of a hindrance, so we hope that

* King's Survey Intertrop. Australia. Append. ii. 1827, p. 477.

† Voy. Rattlesnake, ii. 1832, p. 364.

$\ddagger$ Conch. Icon. x. Mytilus, 1857, pl. viii., f. 26.

$\S$ Moll. Nov. Holl. Specimen, 1843, p. 37.

II David \& Etheridge, Rec. Geol. Survey N.S.W., ii. 1890, p. 49.

- T These Proceedings, xxvi. 1901, p. 21.

* Ann. Mag. Nat. Hist. (5) xvii. 1886, p. 135. 
for the guidance of conchologists Cooke's species may be figured and rehabilitated.

Lima bassir, Tenison Woods.

(Plate ix., fig. 28.)

Several odd valves of a Lima were dredged by Mr. G. H. Halligan and self in 100 fathoms, 16 miles east of Wollongong. At first I regarded it as new, but Mr. F. C. Grant, to whom the fossil is familiar, identified it for me. On comparing Tertiary examples determined by Prof. Tate with our shell, the only difference apparent to me is that the Wollongong specimens, which are probably not full grown, are smaller. Another instance is thus added of survivals from the Miocene epoch. My figure is taken from the New South Wales shell.

Tenison Woods described* the species from the Table Cape beds. It was figured by Prof. Tate, $\uparrow$ who afterwards $\uparrow$ enumerated the localities in which it has occurred. Hutton has united it with his L. colorata, from which Harris|| separates it.

Lima alata, Hedley.

While on the subject of Lima, I may add L. alata to the Australian fauna, on the strength of a single valve which I gathered on the beach of Fitzroy Island, North Queensland, in August, 1901. The species was originally described from Santa Cruz.

Cucullea concamera, Bruguière.

Some imperfect valves which I collected in November, 1898, en the beach at Cape Byron, enable me to add this species to the fauna of New South Wales. North of this point it extends along the whole Queensland coast to Torres Straits, where it was found

* Proc. Roy. Soc. Tas. 1876, p. 112.

+ Trans. Roy. Soc. S.A. vii. 1886, pl.v., f.8, pl.vii., f.l.

$\ddagger$ Op. cit., xxiii., 1899, p. 273.

$\S$ These Proceedings, i. (2), 1887, p. 482.

Cat. Tert. Moll. Austr. 1892, p. 309.

ๆ Rec. Aust. Mus. iii. 1898, p. 84. 
by Haddon.* Thence it ranges south down the Gulf of Carpentaria to Mornington Island, where I collected it in June, 1903.

The species is usually and wrongly cited as C. concamerata, of Martini, who described it in 1777 , but who was preceded by Davila, d'Herbigny, and Favanne. None of these writers were binomial and worthy of citation. The first to apply a binomial name was Bruguièret. In the following year Gmelin renamed it Arca cucullus. $\ddagger$

The fossil from Table Cape recorded as C. concamerata by Tenison Woods $\$$ is pronounced by Tate $\|$ to be really $C$. corioensis, M'Coy. But that which Johnston identified as C. corioensis from Flinders Island is said by Tate ${ }^{* *}$ to be $C$. concamerata.

\section{Arca pistachia, Lamarck.}

Lamarck, Anim. s. Vert. vi. 1819, p. 41.

This species from King Island, Bass Straits, is described thus by Lamarck:-Shell ovate, decussately striate, outside gray, inside brownish-black, beaks close together, interior striated. Length $21 \mathrm{~mm}$. In the Second Edition (vi. p. 468) Deshayes adds in a footnote that it closely resembles Arca fusca, from which it differs by being smaller and by having the interior a rich dark brown.

I submit that the above is an excellent pen portrait of the species afterwards described from Bass Straits by E. A. Smith as A. radula. $\uparrow \dagger$ Lamarck's "intus fusco-nigricante; natibus proximis" are recognition-marks which distinguish the species from Australian congeners.

* Melvill \& Standen, Journ. Linn. Soc. Zool. xxvii., 1899, p. 188.

† Encyclopédie Méthodique, Vers. i. 1789, p. 102.

†Linn. Syst. Nat. xiii. p. 3311.

§ Proc. Roy. Soc. Tas. 1875, p. 15.

\| Proc. Roy. Soc. Tas. 1884, p. 212.

TGeol. Tas. 1888, p. 331.

** These Proceedings, xxvi. p. 437.

t† Rep. Chall. Zool. [xiii. 1885, p. 260, pl. xvii. f. 3. 
Tate \& May have merged* A. radula in Anomalocardia carpenteri, Dunker. The crenulated inner margin figured in that species forbids such a union.

Arca pistachia occurred to me in Twofold Bay, N.S.W., and Miss L. Parkes has taken it in Sydney Harbour

\section{ArCa Lischkei, Dunker.}

(Plate ix., figs. 29-34.)

Arca trapezia, Deshayes; Hanley, Cat. Recent Shells, Append. 1856 , p. 374 , pl. xviii., f. 40 .

Anomalocardia lischkei, Dunker, Novitates Conchologicæ, Moll. Mar. Part xiii., March 1868, p. 115, pl. xxxviii., figs. 14, 15, 16.

Anomalocardia trapezia, Deshayes; Jack \& Etheridge, Geol. Queensland, 1892, p. 641, pl. xxxvi., figs. 10, 11, 12.

In studying Australian marine mollusca, I have found most difficulty in naming, not the rarer forms, but the commonest shells, such as Chione lagopus, Pecten medius, and the present.

Various names have been assigned by London writers to the Sydney Mud-cockle, none of which are satisfactory. The excellent figure and description of an ordinary form of this variable species by Dunker, appears to have hitherto escaped recognition as applying to the Australian shell. Its first appearance in literature is an observation by $\mathrm{J}$. Macgillivray, $\uparrow$ who described it as stacked in heaps, several hundred yards in length and more than twenty feet in depth, in aboriginal kitchen-middens at Broken Bay and Brisbane Water, N.S.W. In a footnote Forbes and Hanley identified the species as Arca trapezia, Deshayes.

But that species, of which $A$. lobata, Reeve, is acknowledged $\S$ by its author to be a synonym, is a native of Semblas, Mexico,

* These Proceedings, xxvi. p. 436.

$\uparrow$ Ann. Mag. Nat. Hist (2) ii. p. 30, July, 1848.

$\ddagger$ Revue Zoologique, Soc. Cuv. ii. Dec., 1839, p. 35s; and Mag. de Zool. 2nd ser. ii. 1840, Moll. Pl. xxi.

$\S$ Conch. Icon. errata to Arca. 
and though approaching in contour is yet distinct from the Australian shell.

Following this determination the species was so recorded from New South Wales by Angas*; from Tasmania by Tenison Woodst; and from South Australia by Tate. + Under this name it was added to the fossil fauna of Table Cape by Johnston, $\$$ and expunged by Pritchard.\|

From a confusion of "trapezia" with "trapezina" it has been catalogued under the latter name from Tasmania by Tate \& May. $\uparrow$ Arca trapezina, Lamk., is a tropical species which, by the mixing of Péron's collection, was, with Arca semitorta and Conus pontificalis, accidentally reported from Tasmania instead of N.W. Australia.

The Challenger Expedition obtained our shell in Sydney Harbour. In the Monograph of the Lamellibranchiata of that Expedition it is classified (p. 266) as Arca gubernaculum, Reeve, a Philippine shell. I conjecture that this identification was based on juvenile examples. The discovery of a Philippine species in Sydney Harbour raises a doubt, which Smith appears to allay by throwing suspicion on the habitat originally assigned to A. gubernaculum. There is evidence, however, that it was correct. The species was described immediately after Cuming's return from the Philippines. Both the species Smith values as synonyms are also stated to be Philippine. Gray** regards A. gubernaculum as a synonym of $A$. japonica, Reeve. Kobelti† records it from Formosa, and Fischer $\ddagger$ from the Gulf of Siam.

Under these circumstances it is reasonable to ask for further evidence before admitting A. gubernaculum as Australian. Arca

* Proc. Zool. Soc. 1867, p. 931.

+ Proc. Roy. Soc. Tas. 1877, p. 55.

† Trans. Roy. Soc. S.A. ix., 1887, p. 102.

§ Proc. Roy. Soc. Tas. 1879, p. 41.

|| Proc. Roy. Soc. Vic. viii. n.s. 1896, p. 134.

- These Proceedings, xxvi., p. 436.

** Ann. Mag. Nat. Hist. (2) xix. p. 371, May, 1857.

t† Conch. Cab. ii. Arca, 1889, p. 108.

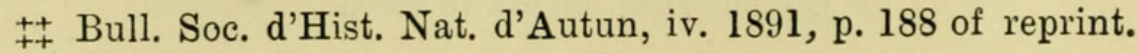


lischkei, so abundant on the coast of New South Wales, fails to attain North Queensland, and becomes rare to the point of extinction in South Australia. It is, therefore, unlikely that it should reach the Philippines. Our shell does not agree with Reeve's figure of A. gubernaculum. Doubtless this is the species reported as Arca globata from Zostera flats at Brisbane by Forbes; ${ }^{*}$ this name is either a MS. one or a misprint.

As subfossil, the species has been noted at Shea's Creek, $\dagger$ at Maitland, $\ddagger$ at Nudgee, $\S$ and as A. antiquata at Deception Bay.\|

From aboriginal middens it has been noted at North Harbour, 9 from the Panbula River, ${ }^{* *}$ and from Bondi. $\dagger \dagger$

The reddish colour of its blood has been remarked by Tenison Woods. 85

As bait for fishing it is in great demand round Sydney. Waite has reported it||| as sold for food in the Sydney fish market, under the name of " cockle."

For the further elucidation of the species, I add figures and a description prepared under the impression that I was dealing with an unnamed species.

Shell very solid, equivalve, oblong, trapezoidal from the side, wedge-shaped from back to front, oblique, inflated, inequilateral. Umbo at the anterior third, elevated, incurved, distant one-quarter of the valve-depth from the hinge-margin. Sculpture: twentynine elevated, strong, radial ribs, parted by flat interspaces of equal breadth; both are traversed by imbricating growth-lines; anteriorly the ribs on both valves carry regularly spaced knots which gradually disappear towards the middle of the shell, and

* Voy. Rattlesnake, ii. 1852 , p. 364.

†Etheridge, David, and Grimshaw, Proc. Roy. Soc. N.S.W. xxx. 1897, p.16.

‡ David and Etheridge, Rec. Geol. Survey N.S.W. ii. 1890, p. 40.

§ Jack and Etheridge, Geol. Queensland, p. 641.

i Jensen, these Proceedings, xxviii. p. 847.

- David and Etheridge, Rec. Geol. Survey N.S.W. i. 1889, p. 142.

** Anderson, Rec. Geol. Survey N.S.W. ii. 1890, pp. 55-57.

t十 Brazier, these Proceedings, xxi. p. 818.

§Proc. Roy. Soc. N.S.W. xxii. 1888, p. 123.

IIII These Proceedings, (2) ix. p. 562. 
which in old age are apt to be worn away. Epidermis dense black, laminate, thinner and usually denuded on the anterior exposure; in youth the epidermis appears as bristles.

Interior porcelain-white, sometimes green under the umbo; the larger ribs imprint within conical crenulations between the pallial line and the posterior ventral margin; pallial sinus very slight. Hinge-line straight and narrow, armed with about twenty-one anterior and twenty-six posterior teeth. In the centre is a sharp break of gauge, the posterior row being considerably smaller, at each end the teeth increase in size and the outermost tumble away from the vertical. Length 52; height 40; depth of separate valve $17 \mathrm{~mm}$.

The species ranges from Bass Straits to Moreton Bay.

Arca lischkei is gregarious and inhabits the soft mud-flats of estuaries. It is sunk up to the umbo obliquely in the mud, and often masked by a tuft of Ulva planted on the anterior end. The swell amidships serves to support the organism from sinking too deeply. Its habits are sedentary.

The asymmetry and wedge-shape appear to have been induced by environment. Parallel development has been carried to an extreme in the case of Arca tortuosa and A. semitorta, which likewise live sunk nearly upright in the mud. Their sharp posterior ends are planted deep in the mud, and the anterior inflations serve to buoy them up on the surface.

The growth of Arca lischkei involves a change in contour, advancing from the symmetry of infancy to asymmetry of youth, and greater degrees of asymmetry in adolescence and senility. A young shell, $3 \mathrm{~mm}$. long, is drawn (fig. 33) to show how the balance of growth is already upset by the preponderance of the posterior side. In another example (fig. 32 ), $11 \mathrm{~mm}$. long, progress in the same direction is continued. It is interesting to observe that an impressed umbonal ray (perhaps an ancestral feature) like that possessed by A. antiquata, Linn., is a prominent feature in the younger shell, is perceptible in the elder, and has disappeared in the adult stage. 
The name Anomalocardia, of Klein, is barred as pre-Linnean by the rules of nomenclature. Those who prefer to break up "Arca" can place this species in Gray's group, Noëtia.

\section{Philobrya inornata, n.sp.}

(Plate x., figs. 40-43.)

Shell very inequilateral, rather inflated, smooth. Colour pale yellow. Sculpture: around the prodissoconch are faint radial wrinkles; beyond, delicate growth-lines are crossed by weak radiating threads, which vanish as the shell ages, leaving the latter part smooth. Hinge-line straight, nearly square with the anterior margin; ventral margin regularly rounded. Prodissoconch subquadrate, flat, with raised margins like a dish. Chondrophore oblique, long and narrow; posterior crenulations faint, anterior in a short bunch of about half a dozen. Inner ventral margin with a few crenulations at the anterior side, feebly denticulate for the remainder of the edge. Height $2 \cdot 0$; length $1 \cdot 14$; depth $0.8 \mathrm{~mm}$.

Hab.- Sixteen miles east of Wollongong in 100 fathoms; several valves were dredged by Mr. G. H. Halligan and myself.

Ty pe.-To be presented to the Australian Museum.

Bernard divided Philobrya into two groups - the first smooth, the second radially ribbed. If, as I shall endeavour to show, Tate's Myrina crenatulifera should be rejected from this genus because of its two adductors, and want of a prodissoconch cap, then the present is the first smooth Australian Philobrya.

Pelseneer transfers this genus to the Arcidæ.*

\section{Philippiella Rubra, n.sp.}

(Plate x., figs. 44-47.)

Shell small, solid, mytiliform, with a tendency to spiral growth, rather inflated. Dorsal posterior and ventral margins arched, anterior straight or concave. Umbo terminal, swollen, without

\footnotetext{
* Expédition Antarctique Belge, Moll. 1903, p. 41.
} 
visible protoconch. Colour uniform red or purple. Externally smooth, coarse irregular concentric sculpture, no radii. Hingeplate broad, widening posteriorly, projecting into the valve. Chondrophore oblique, long, curved, separating two overlapping crenulated bands, one shorter, subumbonal, with fewer stronger lines; the other longer, posterior, with more numerous but weaker crenulations. No marginal teeth. Margin smooth, except on the posterior side, where it is broken into five prominent, interlocking tubercles. Both posterior and anterior adductor scars are visible; the pallial line is apparently simple. Height $3 \cdot 8$; length 2.9 ; diameter of single valve $1.2 \mathrm{~mm}$.

Hab.-Tasmania : Eagle Hawk Neck (type, in shell sand collected by Mrs. C. Hedley, 27 th May, 1903); Ulverston, among kelp roots (Miss Lodder); Scamander River (Miss Lodder)-New South Wales: Long Bay near Sydney, in shell sand (Miss L. Parkes).

Ty p e.-To be presented to the Australian Museum.

The nearest relation to the species above described is Myrina crenatulifera, Tate.* This was apparently shown by Tate to Bernard, who did not recognise it as a Philobrya, but continued it $\dagger$ in the original genus, + from which Tate afterwards transferred it.§ My reference of that species as occurring in waters of this State\| is based on P. rubra. The two species agree in the absence both of the peculiar protoconch of Philobrya and of external radiating sculpture. Tate's species is always brown, mine red; and the mytiliform shape of the novelty further distinguishes it.

The genus Philippiella was instituted by Dr. Georg Pfeffer for the reception of two species from South Georgia. I have not

* Trans. Roy. Soc. S.A. xv. 1892, p. 131, pl. i., figs. 11, $11 \alpha$.

† Journ. de Conch. xlv. 1897, p. 37.

$\ddagger$ Adula should replace the preoccupied Myrina. Vide Marshall, Journ. of Malac. viii. 1901, p. 19.

§ Trans. Roy. Soc. S.A. xxii. 1898, p. 87.

|| These Proceedings, xxvii. p. 17 ; Mem. Aust. Mus. iv. 1902, p. 300.

ๆ Jahrb. wiss. Hamburg, iii. 1886, p. 119. 
seen these Antarctic forms, but judge from the account quoted that they closely resemble Philobrya, but differ by the presence of two adductor muscles and the absence of the dish-shaped protoconch. Rather than suggest a fresh generic name for our pair of uncapped Australian species, I propose to lodge them for the present in Philippiella.

\section{Terebratulina radula, n.sp.}

$$
\text { (Plate x., figs. 48.50.) }
$$

Shell minute, longer than wide, elongate-ovate, not flexed in front. Colour dull white. Beak produced, distally gouged out to meet a large and incomplete foramen which is margined laterally by small deltidial plates. Ventral valve shallower and much shorter than the dorsal, with auricles somewhat like Lima bullata; a juvenile growth-stage is well defined on its apex. Both valves are sculptured by about a dozen bold, radiating granose ribs, which denticulate the ventral margin and are parted by broad, trench-like interstices, the latter roughened by finer grains. On each side these ribs gradually fade away. The auricles of the ventral valve are transversely wrinkled. Loop trapezoidal, complete, with a returning point on the shorter side. Length 2.95 ; height $3 \cdot 85$; breadth of conjoined valves $2 \mathrm{~mm}$.

Hab. - Sixteen miles east of Wollongong, in 100 fathoms; three specimens taken by Mr. G. H. Halligan and myself.

T y p e.-To be presented to the Australian Museum.

From the well developed loop, I regard the individual figured as adult, in which case it is probably the smallest of the genus known. It is also easily distinguished from co-generic forms by the bold, radiating sculpture. Young specimens, one-third the size of the type, with undeveloped loop, differ in contour. These are broader in proportion to their length, and have a general resemblance to Eucalathis murrayi, Davidson.

The Tertiary fossil Terebratulina scoulari, Tate, has a general likeness to our species. 
On the dates of Tenison Woods' Tasmanian Shells.

In some cases G. F. Angas and Tenison Woods described the same shell almost at the same time. It is therefore important to ascertain the exact dates of publication of Tenison Woods' Tasmanian shells. While on a visit to Hobart, I called on the printers to the Royal Society of Tasmania, who most courteously furnished me with the following dates of their Proceedings :-

Proc. R.S. Tas. for 1874 issued May 11, 1875.

$\begin{array}{llll}\text {, } & 1875 & , & \text { March 21, } 1876 . \\ , & 1876 & , & \text { Feb. 27, 1877. } \\ \text {, } & 1877 & \text { " } & \text { June 14, 1879. } \\ \text {, } & 1878 & \text { " } & \text { Feb. 24, 1879. } \\ \text {, } & 1879 & \text { " } & \text { July 21, 1880. }\end{array}$

The volume for 1877 was held over for a considerable time to complete certain tables. Probably Tenison Woods circulated his reprints privately before the appearance of the Proceedings.

In the author's reprint, but not so far as I am aware in the volume proper, there is inserted in reference to p. 135 of Proc. Roy. Soc. Tas. for 1875, a slip dated 18th May, 1876, withdrawing Trophon clathratus in favour of $T$. petterdi.

\section{EXPLANATION OF PLATES.}

Plate viii.

Figs. 1, 2, 3.-Endodonta hookeriana, Johnston; various aspects.

Figs. 4, 5, 6.-Flammulina mathinne, Petterd; various aspects.

Fig. 7.-Heterocyclus petterdi, Smith.

Figs. 8, 9, 10, 11.-Epigrus protractus, Hedley; various aspects, viewed in axial rotation.

Figs. 12, 13, 14.-Strebloceras cygnicollis, Hedley; different aspects and magnified tip.

Figs. 15, 16.-Capulus devotus, Hedley; from the side and beneath.

Fig. 17.--Daphnella cassandra, Hedley.

Fig. 18. - Phos tabidus, Hedley.

Fig. 19.-Lotorium spengleri, Chemnitz; nest and eggs.

Plate ix.

Fig. 20.-Rissoa integella, Hedley.

Figs. 21, 22.-Atys pransa, Hedley. 
Figs. 23, 24, 25. - Stiva ferruginea, Hedley, and its operculum, as seen from each surface.

Figs. 26, 27.-Thraciopsis arenosa, Hedley; exterior of valve and hinge.

Fig. 28. - Lima bassii, Ten. Woods; from a recent example.

Figs. 29, 30, 31, 32, 33, 34.-Arca lischkei, Dunker; adult specimen from the side, within and above; half-grown instance; juvenile specimen and hinge of same.

\section{Plate $\mathrm{x}$.}

Figs. 35, 36, 37, 38.-Chione despecta, Hedley; exterior, interior, superior aspects and hinge.

Fig. 39.-Dacrydium fabale, Hedley, from within.

Figs. 40, 41, 42, 43.-Philobrya inornata, Hedley; exterior, interior, superior aspects and hinge.

Figs. 44, 45, 46, 47.-Philippiella rubra, Hedley; exterior, interior, superior aspects of one individual and hinge of another.

Figs. 48, 49, 50.--Terebratulina radula, Hedley; dorsal, ventral and interior aspects.

Appendix.

Note on Terebra Hedleyi, Tate.

By Eigar A. Smith, Assistant Keeper of Zoology, Natural History Museum, London.

In Volume xxvi., p. 214, of these Proceedings, in a note by the late Professor Tate, it is stated that the Cingulina Brazieri of Angas does not belong to that genus but to Terebra, and because Angas's species-name was already in use in the latter genus, it is changed to Hedleyi. The object of the present note is to point out that the shell in question is not a T'erebra, but was rightly placed by Angas in Cingulina, and consequently the alteration in the specific name was altogether unnecessary.

The mistake I imagine has arisen through the artist having drawn the type just as he saw it, and not recognising the fact that the outer lip of the shell had been broken away, thus giving the aperture a somewhat channelled appearance anteriorly, still not so canaliculate as in Terebra.

Two specimens of this species were presented to the British Museum by Mr. Angas in 1877, one, the type, being exactly like 


\section{$2 \mathrm{BHL}$ Biodiversity Heritage Library}

Hedley, Charles. 1904. "Studies on Australian Mollusca. Part VIII." Proceedings of the Linnean Society of New South Wales 29, 182-211. https://doi.org/10.5962/bhl.part.20159.

View This Item Online: https://www.biodiversitylibrary.org/item/30005

DOI: https://doi.org/10.5962/bhl.part.20159

Permalink: https://www.biodiversitylibrary.org/partpdf/20159

\section{Holding Institution}

MBLWHOI Library

\section{Sponsored by}

MBLWHOI Library

\section{Copyright \& Reuse}

Copyright Status: NOT_IN_COPYRIGHT

This document was created from content at the Biodiversity Heritage Library, the world's largest open access digital library for biodiversity literature and archives. Visit BHL at https://www.biodiversitylibrary.org. 